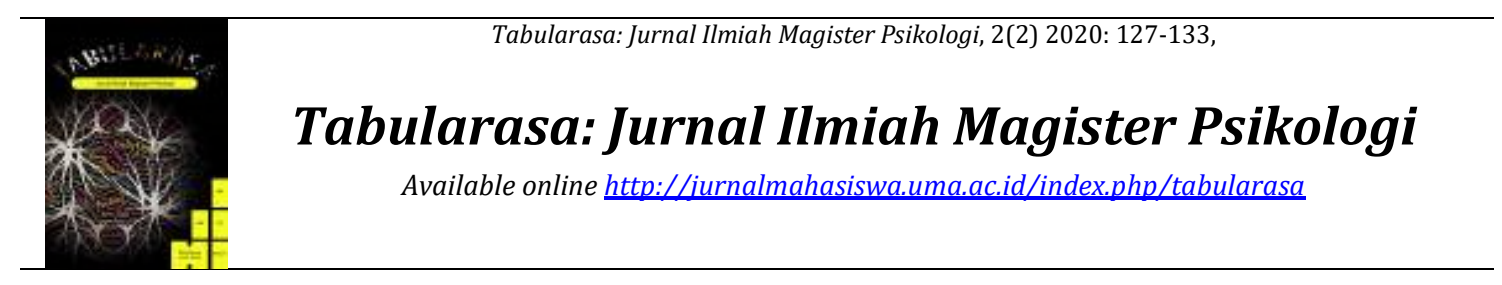

\title{
Pengaruh Model Pembelajaran Kooperatif dan Kecerdasan Emosional Terhadap Tanggung Jawab Siswa Dalam Mata Pelajaran Pendidikan Jasmani Olahraga
}

\section{Effect of Cooperative Learning Model and Emotional Intelligence on Student Responsibility in the Subject of Physical Education}

\begin{abstract}
Roy Bastian Tarigan1), Abdul Munir 2) \& M. Rajab Lubis 2)
1) Magister Psikologi Program Pascasarjana, Universitas Medan Area, Indonesia

2) Jurusan Bimbingan dan Konseling, Fakultas Ilmu Pendidikan, Universitas Islam Negeri Sumatera

Medan, Indonesia

Abstrak

Tujuan penelitian ini adalah : (1) Untuk mengetahui perbedaan pengaruh yang signifikan antara penggunaan metode pembelajaran Student Teams Achievement Divisions (STAD) dan metode pembelajaran Jigsaw terhadap tanggung jawab siswa, (2) Untuk mengetahui perbedaan pengaruh yang signifikan antara siswa yang memiliki kecerdasan emosional terhadap tanggung jawab siswa, (3) Untuk mengetahui interaksi pengaruh antara model pembelajaran dengan kecerdasan emosional terhadap tanggung jawab siswa. Subjek penelitian ini adalah siswa kelas VIII SMP Santo Xaverius 1 yaitu kelas VIII-1 yang menggunakan metode pembelajaran STAD dan kelas VIII-3 dengan menggunakan metode Jigsaw. Hasil penelitian adalah : (1) rata-rata tanggung jawab siswa yang diajar dengan metode pembelajaran Jigsaw $\bar{X}=87.96$ lebih tinggi dari pada hasil belajar siswa yang diajar dengan metode pembelajaran STAD $\bar{X}=66.3$ dengan Fhitung $=1.127<$ Ftabel $=4.006$, (2) rata-rata tanggung jawab siswa dengan kecerdasan emosional tinggi $\bar{X}=86.68$ lebih tinggi dari pada tanggung jawab siswa dengan kecerdasan emosional rendah $\bar{X}=60.76$ dengan Fhitung $=7.749>$ Ftabel $=4.009$, (3) Tidak terdapat interaksi antara model pembelajaran dan kecerdasan emosional terhadap tanggung jawab siswa dengan Fhitung $=2.239<$ Ftabel $=2.683$. Kata Kunci: Model Pembelajaran, Jigsaw, Kecerdasan Emosional, dan Tanggung Jawab Siswa
\end{abstract}

\section{Abstract}

The objectives of this study are: (1) To find out the significant effect differences between the use of Student Teams Achievement Divisions (STAD) learning methods and Jigsaw learning methods on student responsibility, (2) To determine the significant difference in influence between students who have emotional intelligence towards student responsibility, (3) To determine the interaction of influence between learning models and emotional intelligence on student responsibility. The subject of this study was the eighth grade students of Santo Xaverius 1 Junior High School, namely class VIII-1 who used the STAD learning method and class VIII-3 using the Jigsaw method. The results of the study were: (1) the average responsibility of students taught by the Jigsaw learning method $\bar{X}=87.96$ higher than the learning outcomes of students taught by the STAD learning method $\bar{X}=66.3$ with Fcount $=1.127<$ Ftable $=4.006$, (2) the average responsibility of students with high emotional intelligence $\bar{X}=86.68$ higher than the responsibility of students with low emotional intelligence $\bar{X}=60.76$ with Fcount $=7.749>$ Ftable $=4.009$, (3) There is no interaction between learning models and emotional intelligence on student responsibility with Fcount $=2.239<$ Ftable $=2.683$ Keywords: Learning Model, Jigsaw, Emotional Intelligence, and Student Responsibility

How to Cite: Tarigan, R.B. Munir, A. \& Lubis, M.R. (2020). Pengaruh Model Pembelajaran Kooperatif dan Kecerdasan Emosional Terhadap Tanggung Jawab Siswa Dalam Mata Pelajaran Pendidikan Jasmani Olahraga Yayasan Pendidikan SMP Santo Xaverius 1 Kabanjahe, Tabularasa: Jurnal Ilmiah Magister Psikologi, 2(2) 2020: 127-133,

*E-mail: rtagoreputri@gmail.com

ISSN 2550-1305 (Online)

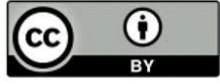

This work is licensed under a Creative Commons Attribution 4.0 
Roy Bastian Tarigan, Abdul Munir \& M. Rajab Lubis, Pengaruh Model Pembelajaran Kooperatif

\section{PENDAHULUAN}

Semua kalangan sepakat bahwa pendidikan karakter adalah penting untuk dilakukan dan diimplementasikan untuk membentuk generasi yang berkualitas. Pendidikan karakter merupakan salah satu alat untuk membimbing seseorang menjadi orang baik, sehingga mampu memfilter pengaruh yang tidak baik.

Dalam UU Nomor 20 Tahun 2003 tentang Sistem Pendidikan Nasional telah dinyatakan dalam BAB II pasal 3 yang memuat fungsi dan tujuan pendidikan. Secara substansial, penjelasan tentang Fungsi dan Tujuan Pendidikan Nasional dalam UU 20 Tahun 2003 diatas, telah meletakkan dan mengarahkan penyelengaraan pendidikan berorientasi pada pembentukan karakter peserta didik. Dengan demikian, pendidikan berbasis karakter dipandang perlu dalam sistem pendidikan nasional.

Dalam mengembangakan karakter khususnya tanggung jawab dibutuhkan strategi pembelajaran yang dapat mengembangakan nilai tanggung jawab tersebut. Strategi penyampaian isi pembelajaran merupakan komponen variabel metode pembelajaran apa yang sesuai untuk melaksanakan proses pembelajaran yang khususnya dapat meningkatkan tanggung jawab pada peserta didik (Hamdani, et al., 2015; Zuraida, et al., 2015). Pada kenyataannya saat ini permasalahan merosotnya nilai karakter pada siswa semakin bertambah dari tahun ke tahun khususnya pada nilai tanggung jawab, kenyataan terjadi dilapangan anak selalu kurang disiplin dan kurang memiliki rasa tanggung jawab seperti tidak membuat pekerjaan rumah, tidak berpakaian dengan rapi, menyerahkan tugas tidak tepat waktu, dan kurang hormat pada guru. Hal ini merupakan dasar dalam pembentukan watak dan karakter kepribadian pada siswa. Kalau kebiasaan ini tidak menemukan pemecahan masalahnya maka tujuan pendidikan nasional akan sulit terwujud (Harahap, et al., 2014; Syarifah \& Darmayanti, 2010; Siregar, 2012).

Salah satu pembelajaran yang dilaksanakan di Sekolah Menengah Pertama adalah Pendidikan Jasmani Olahraga dan Kesehatan (Penjas Orkes). Pendidikan Jasmani Olahraga dan Kesehatan yang diajarkan disekolah memiliki peranan sangat penting, yaitu memberikan kesempatan kepada peserta didik untuk terlibat langsung dalam berbagai pengalaman belajar melalui aktivitas jasmani, olahraga dan kesehatan yang terpilih dan dilakukan secara sistematis. Pembekalan pengalaman belajar itu diarahkan untuk membina pertumbuhan fisik dan pengembangan psikis yang lebih baik, sekaligus membentuk pola hidup yang sehat dan bugar sepanjang hayat.

Selama ini telah terjadi kecenderungan dalam memberikan makna mutu pendidikan yang hanya dikaitkan dengan aspek kemampuan kognitif. Pandangan ini telah membawa akibat terabaikannya aspek-aspek moral, akhlak, budi pekerti termasuk rasa tanggung jawab.

Di samping mengembangkan aspek psikomotorik (keterampilan fisik) dan mengembangkan aspek kognitif (keterampilan intelektual), pembelajaran Penjas Orkes juga mengembangkan aspek afektif (keterampilan moral, emosional, sosial, dan spiritual) (Syarifudin 1997).

Setelah mempelajari Penjas Orkes peserta didik diharapkan mampu bertanggung jawab terhadap dirinya dan terhadap lingkungan sekitarnya sesuai dengan aspek afektif yang yang ditanamkan dalam pembelajaran Penjas Orkes tersebut yaitu peserta didik 
dapat meletakkan landasan karakter yang kuat melalui internalisasi nilai dalam pendidikan jasmani serta mengembangkan sikap sportif, jujur, disiplin, bertanggung jawab, kerjasama, percaya diri, dan demokratis melalui aktivitas jasmani. Namun pada kenyataanya banyak peserta didik maupun orang tua siswa yang belum memahami pentingnya pembelajaran Penjas Orkes dalam proses perkembangan karakter.

Indikator lain menunjukkan peran guru Penjas Orkes di sekolah lebih mementingkan aspek psikomotorik (keterampilan fisik/gerak) ketimbang aspek-aspek yang lain sehingga peserta didik tidak memahami pendidikan karakter yang tertanam dalam pelajaran Penjas Orkes tersebut.

Berdasarkan observasi yang dilakukan di SMP Santo Xaverius 1 Kabanjahe, model pembelajaran yang digunakan oleh guru Penjas Orkes selama ini cenderung menggunakan metode ceramah ataupun metode pembelajaran langsung, dimana yang menjadi pusat pembelajaran adalah guru tersebut sehingga siswa kurang termotivasi dan kurang bertanggung jawab terhadap pelajaran tersebut.

Untuk mencari pemecahan dari permasalahan ini dapat dilakukan dengan menerapkan model pembelajaran yang tepat. Model pembelajaran yang digunakan adalah dengan membawa peserta didik pada suasana belajar yang lebih variatif pada saat pembelajaran berlangsung. Suasana belajar ini dapat dilakukan dengan menggunakan metode STAD (Students Team Achievement Division) dan metode Jigsaw dengan menerapkan metode pembelajaran tersebut diharapkan peserta didik dapat lebih termotivasi sehingga menumbuhkan rasa tanggung jawab terhadap pembelajaran tersebut.

Sementara Trianto (2010) mengemukakan pembelajaran kooperatif STAD merupakan salah satu jenis dari model pembelajaran kooperatif dengan menggunakan kelompok-kelompok kecil dengan jumlah anggota tiap kelompok 4-5 orang siswa secara heterogen. Diawali dengan penyampaian tujuan pembelajaran, penyampaian materi, kegiatan kelompok, kuis, dan penghargaan kelompok.

Agus Suprijono (2009) Model pembelajaran kooperatif jigsaw merupakan pembelajaran kooperatif dimana guru membagi kelas dalam kelompok-kelompok lebih kecil. Selain itu Yuzar dalam Isjoni (2010) mengatakan, dalam pembelajaran kooperatif tipe jigsaw, siswa belajar dengan kelompok kecil yang terdiri 4 sampai 6 orang, heterogen dan bekerja sama saling ketergantungan yang positif dan bertanggung jawab secara mandiri.

Pembelajaran ini dimulai dengan pembelajaran bab atau pokok bahasan, sehingga setiap anggota kelompok memegang materi dengan topik yang berbeda-beda. Tiap siswa dari masing-masing kelompok yang memegang materi yang sama selanjutnya berkumpul dalam satu kelompok baru yang dinamakan kelompok ahli. Masing-masing kelompok ahli bertanggungjawab untuk sebuah bab atau pokok bahasan. Setelah kelompok ahli selesai mempelajari satu topik materi keahliannya, masing-masing siswa kembali ke kelompok asal mereka untuk mengajarkan materi keahliannya kepada teman-teman dalam satu kelompok dalam bentuk diskusi.

Berdasarkan uraian di atas diharapkan siswa dapat meningkatkan rasa tanggung jawab dalam pembelajaran Penjas Orkes tersebut khususnya dalam metode jigsaw, siswa 
diarahkan dalam dua kali pengelompokan yaitu kelompok asal dan kelompok ahli seterusnya siswa bertanggung jawab untuk mempresentasikan materinya kepada teman kelompoknya. Sehingga metode jigsaw ini diharapkan lebih memberikan kontribusi rasa tanggung jawab kepada siswa dari pembelajaran kelompok yang telah dilakukan.

Dari pemaparan tersebut, dibuatlah hipotesis dari penelitian ini, yaitu:

1. H1 : Ada perbedaan pengaruh antara metode pembelajaran Student Teams Achievment Divisions dengan metode pembelajaran Jigsaw terhadap tanggung jawab pada siswa dalam mata pelajaran Penjas Orkes.

2. H2 : Ada perbedaan antara siswa yang memiliki kecerdasan emosional tinggi dengan siswa yang memiliki kecerdasan emosional rendah terhadap tanggung jawab pada siswa dalam pembelajaran Penjas Orkes.

3. H3 : Ada interaksi antara penggunaan model pembelajaran dengan kecerdasan emosional terhadap nilai tanggung jawab pada siswa dalam mata pelajaran Penjas Orkes.

\section{METODE PENELITIAN}

Penelitian ini menggunakan metode eksperimen dengan rancangan quasi eksperimen desain factorial $2 \times 2$. Dengan melakukan eksperimen yang sudah tersedia sebagaimana adanya tanpa melakukan perubahan situasi kelas dan jadwal pembelajaran, sedangkan karakteristik siswa yang dikontrol adalah kecerdasan emosional, sedangkan perlakuan yang dilaksanakan adalah metode pembelajaran Jigsaw dan Student Teams Achievement Divisions pada mata pelajaran Pendidikan Jasmani Olahraga dan Kesehatan.

Dalam penelitian terdapat variabel penelitian yang terdiri dari variabel terikat yaitu karakter tanggung jawab pada pembelajaran penjas orkes, variabel bebas aktif yaitu metode pembelajaran Student Teams Achievement Divisions dan metode pembelajaran Jigsaw dan variabel moderatornya yaitu kecerdasan emosional terdiri dari kecerdasan emosional tinggi dan kecerdasan emosional rendah.

Uji coba instrument dilakukan dengan skala tanggung jawab dengan menggunakan skala Likert. Skala Likert menurut Djaali (2008) ialah skala yang dapat dipergunakan untuk mengukur sikap, pendapat, dan persepsi seseorang atau sekelompok orang tentang suatu gejala atau fenomena pendidikan. Uji coba ini selanjutnya diberikan kepada siswa yang masuk dalam sampel penelitian yaitu kelas VIII ${ }^{1}$ (Student Teams Achievement Divisions) dan kelas VIII ${ }^{3}$ (Jigsaw).

\section{HASIL DAN PEMBAHASAN}

H1 : Tanggung jawab siswa yang diajar dengan metode pembelajaran Jigsaw lebih tinggi dari tanggung jawab siswa yang diajar dengan menggunakan metode pembelajaran Student Teams Achievement Divisions. Berdasarkan hasil analisa statistik diketahui secara keseluruhan rata-rata tanggung jawab siswa SMP Santo Xaverius 1 Kabanjahe yang diajar dengan metode pembelajaran Jigsaw $(\bar{X}=87.96)$ lebih baik dari pada rata-rata tanggung jawab siswa SMP Santo Xaverius 1 Kabanjahe yang diajar dengan metode pembelajaran STAD ( $\bar{X}=66.3)$. Hal ini menunjukkan bahwa metode pembelajaran Jigsaw 
terbukti efektif dapat meningkatkan tanggung jawab siswa secara keseluruhan baik untuk kelompok kecerdasan emosional tinggi maupun kecerdasan emosiona rendah.

$\mathrm{H} 2$ : Tanggung jawab siswa yang memiliki kecerdasan emosional tinggi lebih tinggi dari pada tanggung jawab siswa yang memiliki kecerdasan emosional rendah. Berdasarkan hasil analisa statistik diketahui tanggung jawab siswa yang diajar dengan model Jigsaw dan kecerdasan emosional tinggi ( $\bar{X}=86.68)$ lebih baik dari pada tanggung jawab siswa dengan kecerdasan emosional rendah $(\bar{X}=60.76)$. Hal ini menunjukkan bahwa Kecerdasan Emosional Tinggi signifikan untuk membedakan tanggung jawab siswa, tanggung jawab siswa dengan kecerdasan emosional tinggi lebih baik diajarkan dengan metode pembelajaran Jigsaw.

H3 : Tidak terdapat interaksi antara penggunaan model pembelajaran dengan kecerdasan emosional dalam mempengaruhi tanggung jawab siswa. Bagi siswa dengan kecerdasan emosional tinggi dan kecerdasan emosional rendah lebih tinggi diajar dengan metode pembelajaran Jigsaw dari pada metode STAD. Berdasarkan hasil analisa statistik diketahui apabila dilihat dari rata-rata tanggung jawab siswa dengan kecerdasan emosional tinggi dan siswa yang diajar dengan metode pembelajaran Jigsaw lebih tinggi ( $\bar{X}=89.78$ ) dibandingkan dengan rata-rata tanggung jawab siswa dengan kecerdasan emosional tinggi dengan metode pembelajaran STAD $(\bar{X}=62.5)$. Kemudian rata-rata tanggung jawab siswa dengan kecerdasan emosional rendah yang diajar dengan metode pembelajaran Jigsaw ( $\bar{X}=62.5$ ) lebih tinggi dibandingakan dengan rata-rata tanggung jawab siswa dengan kecerdasan emosional rendah yang diajarkan dengan metode pembelajaran STAD $(\bar{X}=60.45)$.

\section{SIMPULAN}

Jika dikaitkan dengan kegiatan pembelajaran Pendidikan Jasmani Olahraga dan Kesehatan, model pembelajaran Jigsaw yang diterapkan dapat mengakomodasi berbagai pendekatan yang digunakan untuk membentuk suatu rangkaian pembelajaran dimana pada pembelajaran Pendidikan Jasmani Olahraga dan Kesehatan disamping menekankan aspek psikomotorik (keterampilan) juga menekankan aspek afektif (moral dan sikap) seperti sikap tanggung jawab.

Model pembelajaran Jigsaw tidak hanya proses dalam keterampilan saja tetapi juga melibatkan proses interaksi setiap anggota dalam kelompok sehingga tercipta rasa tanggung jawab setiap peserta didik untuk meningkatkan keberhasilan kelompoknya. Dalam pembelajaran Pendidkan Jasmani Olahraga dan Kesehatan model pembelajaran Jigsaw dapat menentang kemampuan siswa serta memberikan kepuasan untuk menemukan pengetahuan baru bagi siswa, dapat meningkatkan efektivitas pembelajaran siswa, dapat membantu siswa untuk mengembangkan pengetahuan barunya dan bertanggung jawab dalam pembelajaran yang mereka lakukan, dapat mengembangkan kemampuan siswa untuk berpikir lebih kritis dan mengembangkan kemampuan mereka untuk menyesuaikan dengan pengetahuan, dapat memberikan kesempatan kepada siswa untuk mengaplikasikan pengetahuan yang mereka miliki dalam dunia nyata, dan dengan model pembelajaran Jigsaw, keaktifan siswa dalam belajar akan mudah terbentuk, yang 
Roy Bastian Tarigan, Abdul Munir \& M. Rajab Lubis, Pengaruh Model Pembelajaran Kooperatif

pada akhirnya akan menjadi kebiasaan dalam menyelesaikan berbagai permasalahan yang ditemuinya dalam aktivitas kehidupan nyata sehari-hari ditengah masyarakat.

\section{DAFTAR PUSTAKA}

Arends, R. (1989). Learning to Teach, New York: Me Graw Hill Book Company

Arikunto, S. (2007). Dasar-Dasar Evaluasi Pendidikan. Bumi Aksara. Jakarta.

Asman, M.J. (2011). 7 Tips Aplikasi Pembelajaran Aktif, Kreatif, Efektif, dan Menyenangkan. Diva Press. Jogjakarta.

Babaei, M., \& Cheraghali, M. R. (2016). The Effectiveness of Training The Context of Life Skills Book on the SelfConfidence Of the First Grade High School Girls in Mazendaran Province. Journal Of Current Research in Science.

Chaplin, J.P (1992). Fungsi Pengembangan dan Pengukuran Prestasi Belajar. Yogyakarta. Pustaka Belajar

Dimyati \& Mudjiono, (2006). Belajar dan Pembelajaran. Jakarta: Rineka Cipta

Dimyati dan Mudjiono. (1999). Belajar dan Pembelajaran. Jakarta: Rineka Cipta

Djamarah, Bahri, S, dan Aswan, Z. (2006). Strategi Belajar Mengajar. Rineka Cipta. Jakarta.

Djamarah. (2005). Strategi Belajar Mengajar. Jakarta: Rineka Cipta

Gagne, R.M. (1975). Essentials of Learning for Instructions. Illionis: The Dryden Press.

Gagne, R.M. (1985). The Conditions of Learning and Theory of Instructions. New York: Holt Rinehart and Winston.

Ginsburg, H. \& Magoon, R.A. (1972). Educational Physicology: An Integration of Physicology and Educational Practices. Colombus, Ohio: Charles E. Merril Publishing Company.

Gulo W. (2002). Strategi Belajar Mengajar. Gramedia Widiasarana Indonesia. Jakarta.

Hamdani, R., Lahmuddin L., Aziz, A., (2015), Hubungan antara Dukungan Sosial dan Kecerdasan Emosional dengan Self-Regulated Learning Siswa. Analitika: 7 (2): 105-117

Harahap, E.R., Ferry N., Gustiarti L., (2014), Peranan Kohesivitas Kelompok Dan Kecerdasan Emosional Terhadap Organizational Citizenship Behavior, Analitika: 6 (1): 1-10

Hawari Aka (2012). Guru Yang Berkarakter Kuat. Yogyakarta: Laksana

Ibrahim, M. et. All (2000). Pembelajaran Kooperatif. Surabaya: Universitas Negeri Surabaya

Isjoni. (2009). Pembelajaran Kooperatif. Yogyakarta: Pustaka Pelajar

Jhonson \& Jhonson. (1994) Cooperatif Learning in The Classroom. Virginia, Association for Supervision and Curriculum Development

Jhonson, E.B. (2002) Contekxtual Teaching and Learning. California: Convin Press, Inc.

Josephson, M.S., Peter, V.J., \& Dowd, T. (2003). Menumbuhkan 6 Sikap Remaja Idaman Panduan bagi Orangtua. (E. A. Budihabsari, Penerj.) Bandung: Kaifa.

Joyce, B, Well. M. Calhoun, E (2000). Model Of Teaching. London: Allyn and Bacon

Khairil, S.D. (2010). Psikologi Pendidikan. Alfabeta: Bandung

Kurniasih, Imas dan Berlin Sani. (2017). Pendidikan Karakter. Kata Pena. Jakarta

Lardika, Rola, Angga "Model-Model Pembelajaran Penjaskesrek" $20 \quad$ Februari 2015. https://rolaanggalardika.wordpress.com

Muhibbinsyah. (2010). Psikologi Pendidikan Dengan Pendekatan Baru. Remaja Rosdakarya. Bandung.

Munir, A. 2010. Pendidikan Karakter Membangun Karakter Anak Sejak dari Rumah. Yogyakarta: PT Pustaka I nsan Madani.

Mustari Mohamad. (2011). Nilai Karakter. LaksBang PRESSindo. Yogyakarta.

Mylsidayu Apta. (2014). Psikologi Olahraga. Bumi Aksara. Jakarta

Nur, M. (2000). Pengajaran Berpusat Kepada Siswa dan Pendekatan Konstruktivisme dalam Pengajaran. Surabaya: Universitas Negeri Surabaya.

Purwanto, Ngalin. (1997). Psikologi Pendidikan. Bandung: PT. Remaja Karya.

Ratnawilis, D. (2001). Teori-Teori Belajar. Jakarta: Airlangga.

Reigeluth, Charles M. and Carr-Chellman, Alison A (2009). Instructional-Design Theories and Models. New York, London: Routledge Taylor and Francis, Publishers.

Sanjaya, Wina. (2008). Perancanaan dan Desain Sistem Pembelajaran. Jakarta: Kencana

Sanjaya, Wina. (2008). Strategi Pembelajaran. Jakarta: Kencana

Santrock W, John (2008). Psikologi Pendidikan. Kencana. Jakarta.

Sherly Juwita (2015). Pengaruh Model Pembelajaran Koopertif dan Kecerdasan Intelektual Terhadap hasil Belajar Ilmu Pengetahuan Sosial SMP AS-SYAFI'IYAH Medan. Jurnal Unimed.

Slameto. (2003). Belajar dan Faktor-Faktor yang Mempengaruhinya. Jakarta: Rineka Cipta

Slavin E, Robert. (2008). Psikologi Pendidikan Teori dan Praktik. Indeks. Jakarta.

Sudjana. (2005). Metoda Statistika. Tarsito. Bandung. 
Suprijono, A. (2010). Metode dan Model-Model Belajar. Bandung. Alfabeta Syarifah, Nefi D., (2010), Pengaruh Locus Of Control dan Kecerdasan Emosional terhadap Kemampuan Memecahkan Masalah pada Remaja Desa Percut Kecamatan Percut Sei Tuan, Analitika: 2 (2): 88-98.

Zuraida, Kaiman T, Sri S, (2015), Hubungan Kecerdasan Emosional dan Dukungan Sosial Keluarga dengan Burnout, Analitika: 7 (2): 141-149 